\title{
When the first language feels like a second language: Challenges for learners of Norwegian Nynorsk
}

\author{
JENS HAUGAN
}

Received 21.01.2019,

received in revised form 29.03.2019,

accepted 11.04.2019.

\begin{abstract}
Norway has two official written language varieties: Bokmål (DanoNorwegian) and Nynorsk (New Norwegian). Normally, all Norwegian pupils must learn both varieties of the written Norwegian language in school, and at the end of secondary school, they obtain two separate grades in written Norwegian. However, one of the varieties is considered to be and is taught as the main written language, whereas the other variety is the second or alternative written language.

Approximately 85 percent of the pupils in school have the DanoNorwegian variety as their main written language and many of these pupils develop antipathies toward the other variety with the result that they do not master it very well at the end of secondary school. In fact, many pupils achieve better results in English than in the alternative variety of their own so-called mother tongue.

In this paper, I will discuss some of the challenges that are related to learning Nynorsk in the Norwegian educational system and society. With reference to Norton (2013) and others, I will argue that these challenges may actually be best understood from the perspectives of identity, social power, motivation, investment and second language acquisition.
\end{abstract}




\title{
Keywords
}

language teaching, language learning, language acquisition, language didactics, language politics, identity, investment, motivation, social power, Norton, Nynorsk

\section{Kiedy pierwszy język jest bardzo podobny do drugiego języka: Wyzwania dla uczniów norweskiego Nynorsk}

\begin{abstract}
Abstrakt
Norwegia ma dwie oficjalne odmiany języka pisanego: Bokmål (DanoNorwegian) i Nynorsk (New Norwegian). Zwykle wszyscy uczniowie w Norwegii muszą uczyć się obu odmian języka norweskiego pisanego w szkole, a pod koniec szkoły średniej otrzymuja dwa oddzielne stopnie $z$ języka norweskiego. Jednak jedna $z$ odmian jest uznawana i nau-czana jako główny język pisany, podczas gdy druga odmiana jest drugim lub alternatywnym językiem pisanym.

Około 85 procent uczniów w szkole uczy się odmiany duńskonorweskiej jako swojego głównego języka pisanego, a wielu $z$ tych uczniów rozwija u siebie antypatię do drugiej odmiany, w wyniku czego nie opanowuja jej zbyt dobrze pod koniec szkoły średniej. W rzeczywistości wielu uczniów osiaga lepsze wyniki w języku angielskim niż w drugiej odmianie własnego języka ojczystego.

W tym artykule omówię niektóre wyzwania związane $z$ nauka Nynorsk w norweskim systemie edukacyjnym i społeczeństwie. Odnosząc się do Nortona (2013) i innych, będę dowodził, że te wyzwania moga być najlepiej zrozumiane $z$ perspektywy tożsamości, siły społecznej, motywacji, inwestycji i przyswajania drugiego języka.
\end{abstract}

\section{Słowa kluczowe}

nauczanie języka, nauka języków, nabywanie języków, dydaktyka językowa, polityka językowa, tożsamość, inwestycja, motywacja, siła społeczna, Norton, Nynorsk 


\section{Introduction}

This paper was presented at the third international conference "Educational Role of Language" (ERL) at the Lithuanian University of Educational Sciences in Vilnius in June 2018 (ERL 3, 2018). When preparing for this third ERL conference, I decided to have a more theoretical perspective on the topic of my presentation than at the first ERL conference (Haugan 2016, 2017) where I discussed whether Norwegian Nynorsk as an alternative written variety should be seen as the first language (L1) for Norwegian pupils or rather as a second language (L2).

Norway has two official written language varieties: Bokmål (Dano-Norwegian) and Nynorsk (New Norwegian) (see e.g. Wardhaug 2010: chap. 2; Haugan 2017). Unless one is exempt from learning (to write) the alternative variety (for instance because of dyslexia or because of another first language), all Norwegian pupils must learn both varieties of written Norwegian at school. At the end of secondary school, the pupils obtain two separate grades in written Norwegian. However, one of the varieties is considered and taught as the main written language, whereas the other variety is seen as the second or alternative written language (see Haugan 2017).

Approximately 85 percent of Norwegian pupils have the Dano-Norwegian variety (Bokmål) as their main written language and many of these pupils develop antipathies toward the other variety (Nynorsk) with the result that they do not master it very well at the end of secondary school. In fact, many pupils achieve better results in English than in the alternative variety of their own so-called mother tongue.

Teaching and learning Nynorsk as an alternative written variety of Norwegian comes with many challenges (see e.g. Haugan 2017, and references there). Therefore, teachers and learners need a better understanding of the conditions for teaching and learning the alternative written language. Since the two written varieties of Norwegian are taught within the same school subject (Norwegian), and since they are 
considered to be written varieties of the same first language ("mother tongue"), teachers and learners might not be aware of the benefits of approaches to second language acquisition that might help them to achieve better results.

The main question of this paper is whether it is possible to both understand and explain the challenges for Nynorsk as an alternative written variety of Norwegian from the theoretical approaches of, among others, Norton (2013) and Dörnyei (2009), who focus on key terms like identity, investment, social power, motivation and the so-called L2 self. I will try to show that these terms could explain why many pupils manage to learn English as a second language rather well while at the same time they meet greater obstacles when it comes to learning Nynorsk as a variety of the first language.

\section{Methodological and theoretical foundations}

The present paper is a contribution to the work of the Educational Role of Language (ERL) network that was established in 2016 on the basis of an initiative from the Division of Research on Childhood and School, Department of Education at the University of Gdańsk. I have been a member of the ERL network since 2016 and the following short presentation is partly based on Haugan (2018b).

The ERL network consists of researchers from many fields, not only pedagogy, language teaching and linguistics, but also psychology, philosophy and other disciplines that may have an interest in the role of language in a broader perspective. The main goal of the ERL network is to bring together academics whose work and interests combine language and educational science. Following the rationale of the "linguistic turn", network members jointly study how language shapes our understanding of the world and people's functioning in it. There is a variety of projects with different perspectives on language beliefs, language activity, language experience and/or language matrices of world interpretation. Hence, the 
network projects fall within the worldview, psychomotor, affective and/or cognitive domain.

To systematise the scope of the ERL network, four key areas were established when the project started in 2016:

- Potential of Language for General Education,

- Language Activity of Children,

- Personal Experience of Language,

- Language Matrixes of Reality Interpretation.

In order to make room for more academics to join the network, these key areas were renamed in 2017:

- Language Beliefs,

- Language Activity,

- Language Experience,

- Language Matrixes.

When preparing for the third ERL conference it was relevant to see how my approach to Norwegian Nynorsk as an alternative written variety of Norwegian would fit with the main goals of the Educational Role of Language network. The name of the network opens up three perspectives, which in itself is worth reflecting upon as a starting point.

Educational relates to education, i.e. in the context of the ERL network, a planned and organized municipal or state activity where children, adolescents or possibly adults are supposed to acquire and develop knowledge and skills according to certain curricula (see e.g. Schmidt et al. 2001). A curriculum is normally divided into general goals and concrete goals. General goals are often related to a general educational approach, which may be easier to understand by referring to the German distinction between the terms Bildung (liberal education) and Ausbildung (formal education, schooling) (see e.g. Schaffar and Uljens 2015). Simply put, one might say that the Bildung aspect of education is often associated with the general expectations a society may have 
with regard to general knowledge about certain subjects. Lack of Bildung is often considered a negative personality trait by many members of a modern so-called "knowledge society" (see e.g. Hargreaves 2003, for a discussion on knowledge society). As for Norwegian society, the national curriculum for Norwegian as a school subject (Læreplan i norsk (NOR1-05)) expects all pupils (with certain exceptions) to master both written varieties of Norwegian, Bokmål and Nynorsk, at the end of secondary school, since both varieties are a part of Norwegian society, culture and history. This may be considered the Bildung aspect of it. The general part of the curriculum for Norwegian as a school subject, thus, starts with stating that "Norsk er et sentralt fag for kulturforståelse, kommunikasjon, dannelse og identitetsutvikling”, i.e. Norwegian is a central subject for cultural understanding, communication, education (here with the meaning of Bildung) and identity development. The national curriculum for Norwegian as a school subject furthermore states:

I Norge er norsk og samisk offisielle språk, og bokmål og nynorsk er likestilte skriftlige målformer. Vi bruker mange ulike dialekter og talemålsvarianter, men også andre språk enn norsk. Det språklige mangfoldet er en ressurs for utviklingen av barn og unges språkkompetanse. Med utgangspunkt i denne språksituasjonen skal barn og unge få et bevisst forhold til språklig mangfold, og lære å lese og skrive både bokmål og nynorsk. Formålet med opplæringen er å styrke elevenes språklige trygghet og identitet, utvikle deres språkforståelse og gi et godt grunnlag for mestring av begge målformene i samfunns- og yrkesliv.

'Norwegian and Sámi are official languages in Norway, and Bokmål and Nynorsk are equal written varieties. We use many different dialects and variants of oral speech, but also other languages than Norwegian. The linguistic diversity is a resource for the development of children's and adolescents' linguistic competence. Based on this language situation, children and adolescents shall develop a conscious relationship to linguistic diversity and learn to read and write both Bokmål and Nynorsk. The purpose of the education (schooling) is to strengthen the 
students' linguistic self-confidence and identity, develop their understanding of language and provide a good basis for mastering both of the written varieties in the society and in professional life.' (my translation)

When it comes to the Ausbildung (formal schooling) aspect of education, much less effort is put into teaching the alternative variety, which for about $85 \%$ of the pupils is Nynorsk. From that perspective, one might say that the official educational system in Norway works according to a double standard. By operating with official terms like "main language" (hovudmål) and alternative or "side language" (sidemå), the official curriculum seemingly treats the two varieties as having different values. This permits an interpretation, by both teachers and students, that the alternative written language is less important than the main language.

Education is obviously also politics. National curricula are a state matter belonging to the Ministry of Education and Research and the Directorate for Education and Training (see udir.no). The two written varieties of Norwegian have actually had official and equal status since 1885, and the distribution of Bokmål users and Nynorsk users was relatively even before the Second World War. Even though it is not that easy to measure the actual number of those with Nynorsk as their main written language in the Norwegian society today, it is usually assumed that approximately $12-15 \%$ or ca. 600000 , prefer to write Nynorsk (see e.g. Grepstad 2015). 12-15\% may not seem to be considerable, but this is still a substantial amount of potential voters in a democracy. Another perspective, though, may be that operating with two official written languages in the educational system and in state matters has, of course, also a financial aspect. A returning political question (mostly from conservatives) is, therefore, whether it is "worth" keeping two official written languages with the obvious underlying rhetorical statement that the major form, Bokmål, should be the only official written Norwegian language. 
Let us take a brief look at the second word of the ERL network name: Role. Two questions may arise: what role does education play, and what part does language play? Role as a term may refer to a more or less active choice to have a certain place or status in a given situation. From the perspective of the Norwegian educational system, one might ask what impact the curriculum has on the treatment of the two written varieties of Norwegian. From the perspective of the individual student, then, one might ask about the status of language (either or both of the official written languages) in education. One aspect would be to what degree the state and official politics would play an active part in the language education of the students. Another aspect would be to what degree the individual student would play an active role in his or her own use of language(s). These two aspects meet at certain points in the educational system or in society; for instance, when failing to master the alternative written language, i.e. the lesser appreciated "side language", becomes a hindrance for entering higher education or getting jobs where this language is used as the main language.

The word language in the ERL network may be selfexplanatory. However, certain relevant questions arise when trying to relate this to Nynorsk as an alternative written language in Norway. Is Nynorsk your main written language and is it, therefore, your first language or so-called "mother tongue"? What "language" do you actually speak? In Norway, most people speak local or regional dialects instead of standard (written) language. Therefore, for most people, neither of the written varieties is an exact representation of the actual spoken language.

As for the educational system, one recurring question is whether it would suffice for the students to only learn to read the alternative written language instead of having to learn to write it too. Yet another question is the role and the impact of the written language in actual learning activities. Occasionally, it is claimed by some who want to remove the official status of Nynorsk as an equal language, that Nynorsk, since it is based 
on the dialects of "simple" people, (due to the fact that the "founder" of Nynorsk, Ivar Aasen, almost exclusively collected words from rural areas to form a genuine Norwegian language that was free(er) from Danish and German influence (see e.g. Haugen, 1965)), is not equally suitable as a language in learning activities. Bokmål, by contrast, being based on the Danish language with hundreds of years of development in academia and state affairs, is a much "better" language for critical and academic thinking and writing, some people claim (e.g. Norsk språkforening). There is indeed a crucial difference in the style of Nynorsk and Bokmål, since many of the complex nouns in Bokmål are preferably expressed as verbal constructions, e.g. instead of "understanding is important" one would usually rather write "it is important to understand".

Another challenge in Norwegian society and its educational system is the total dominance of Bokmål in academic writing (and writing in general), leading to a situation where most students only know certain expressions and terminology in Bokmål, which might be an extra challenge when reading school texts in Nynorsk. From my personal experience reading student papers, I notice that some students may even have problems dealing with differences as simple as, for instance, the Nynorsk word "forståing" (understanding) for the Bokmål version "forståelse". In other cases, the difference may be greater, e.g. Nynorsk "dugleik" (skill) for Bokmål "ferdighet". In many cases, especially in higher education, e.g. teacher education, students would have to write an academic essay on a certain subject using the alternative written language, and students may fail the exam because of poor language skills even though the content of the paper might have been acceptable. This, of course, also raises the questions whether it is "good" educational practice to make students elaborate on academic subjects in a language they do not master very well.

As we have seen, the title of the ERL network is highly relevant in itself and leads to certain reflections when one is interested in trying to understand the challenges for Nynorsk as an alternative written language in the Norwegian 
educational system. In the next section, I will discuss the research areas of the ERL network as another fruitful starting point, those areas being: Language Beliefs, Language Activity, Language Experience, and Language Matrixes.

In addition to discussing the challenges for Nynorsk as an alternative written language from the general perspectives of the ERL network, I will refer to the research by Norton (2013) and Dörnyei (2009). Norton, Dörnyei and other researchers within more recent approaches to second language acquisition offer new perspectives that may help answer some of my questions. Key terms will here be language identity, social power, motivation and investment.

\section{Discussion}

The ERL network has established certain premises for its research activities (see the ERL research link):

Considering the fact(s) that every school determines

- what students think OF language, i.e. students' LANGUAGE BELIEFS (students' views on listening, speaking, reading, and writing)

- how students feel ABOUT language, i.e. students' LANGUAGE EXPERIENCE (students' emotions concerning listening, speaking, reading, and writing)

- what students do WITH language, i.e. students' LANGUAGE ACTIVITY (students' actions consisting in listening, speaking, reading, and writing)

- how students perceive THROUGH language, i.e. students' LANGUAGE MATRICES (students' world image as shaped by listening, speaking, reading, and writing)

on the level of an individual, society, culture and reality, $[\ldots]$

When looking at these premises, I noticed that they form a kind of causality chain. Is it not so that what we believe will also have an impact on how we actually experience certain 
things? And is it not so that we usually act in accordance with our beliefs and earlier experiences? The first three premises, then, would have an impact on how we perceive the world. In the following discussion, I will look at Norwegian students with Nynorsk as their alternative written language from the first three perspectives: Language Beliefs, Language Experience and Language Activity.

How can we possibly investigate a student's language beliefs about Norwegian? To start with, all Norwegian children learn to locate Norway on a world map as "their" country. Furthermore, they learn that the name of the language in Norway is Norwegian, which is substantiated by the fact that there are books, websites or possibly phone apps named "Norsk ordbok", Norwegian dictionary. These things indicate that a language called Norwegian exists and that this language is tightly connected to the country of Norway. Compared to the names of other countries and (at least one of) their languages, it is also easy to observe and accept that there is, in most cases, a direct linguistic correlation between the name of a country and its official language, e.g. Poland - Polish, Russia

- Russian, Germany - German, Sweden - Swedish, and apparently Norway - Norwegian. Relatively early, then, a Norwegian child would develop a feeling of language identity (Norton 2013, Dörnyei 2009) connected with the term Norwegian.

However, when learning about Norway as a country, one soon also learns that Norway has two official Norwegian languages, Bokmål and Nynorsk. Furthermore, one learns that Sámi is an official language in Norway. Hence, the belief about one language - a "mother tongue" for citizens of Norway - is seriously challenged by the academic experience in school. The written language the majority of children start to learn in school is Bokmål, the name of this variety being a historical compromise from the time when the Danish version of Norwegian was not considered genuine Norwegian (see Haugan 2017). Suddenly, there is a terminology mismatch. There is norsk (Norwegian) as an adjective or as a possible name for the 
language, but the written language is called Bokmål (literally "book language").

During the first few years in school, the children with Bokmål as their main language are usually not exposed to the alternative written language, Nynorsk (New Norwegian), to the same degree. As a result, most children - and teachers - begin to distinguish between Norsk and Nynorsk in everyday speech, with Norsk only referring to Bokmål, the most dominant written language and their main written language. This can be understood as a consequence of the relationship between the ERL terms Language Beliefs and Language Experience. The children already believe that they speak Norwegian, which is the official name of the language including all dialects and all written varieties and an adjective naming everything that is related to Norway as a noun. The language they learn to write in primary school thus, should naturally be called Norwegian. Furthermore, the alternative variety is called New Norwegian, hence, the name pair Norwegian and New Norwegian. At this point, it is easy to understand from a linguistic point of view that the word Norwegian, which functions as an adjective and direct derivation from the word Norway, is the more natural word, whereas New Norwegian states that there is something new and different - and apparently unnecessary, at least from a child's point of view. In primary school, no children know about political history or language history. Their language identity is Norwegian, not "New" Norwegian.

This is also reflected in the use of Norwegian, i.e. Language Activity. The main written language, Bokmål for the majority of children, is used in all subjects in school, in teaching, reading and writing. Bokmål is also the written language that is totally dominant outside of school in more or less all public and private domains. The only language activity related to Nynorsk is usually sporadic listening to texts in Nynorsk read by the teacher in primary school. After some time, there is also sporadic reading of texts in Nynorsk. In most cases, students practice writing more frequently in Nynorsk first in lower secondary school. Hence, in an overall perspective, for the 
majority of Norwegian students there is minimal language activity related to Nynorsk - even though the Norwegian state and the curriculum, seen from a Bildung perspective, expects all students to master both written varieties by the end of upper secondary school.

This brings us to the perspective of Motivation (Norton 2013; Dörnyei 2009). For the majority of Norwegian children the beliefs, experiences and activities related to Norwegian as a language are connected to Bokmål, which consequently becomes synonymous with Norwegian as a general term. Bokmål is the written language most students believe to be their natural language ("mother tongue"), experience to be omnipresent in the Norwegian society including the educational system, and practice (cf. activity) themselves on a daily basis. Nynorsk, on the other hand, is more or less nonexistent (from the perspective of students) in everyday life - at least this is what many students seem to believe, since it is relatively easy to avoid reading texts in Nynorsk outside school. Experience with Nynorsk, thus, is related to mandatory school activities. Furthermore, more systematic teaching - and grading - in Nynorsk is postponed until the $8^{\text {th }}-10^{\text {th }}$ grade in lower secondary school and is continued into upper secondary school where the students obtain a separate grade in Nynorsk.

Students do not normally share the state's official Bildung perspective on the necessity of mastering both written varieties of the Norwegian language. Students have their beliefs, experience and activity connected to Norwegian, which, by the time they reach lower secondary school, when they are supposed to be officially graded in Nynorsk, is minimal. At the time of lower secondary school, most children also reach puberty, which often correlates with a general rebellion against mandatory tasks and other aspects of the adult world. At this stage in life and in education, many students develop a strong antipathy toward learning Nynorsk (see e.g. Garrett 2010, on attitudes to language). Unfortunately, many teachers - having been a part of the same educational system and society share the same antipathy against the alternative language (see 
e.g. Nordal 2004 and Nordhagen 2006). Consequently, the beliefs about Nynorsk (language attitude) and the experience with this language are not necessarily corrected or altered in any way by the teachers, i.e. the official educational system. On the contrary, the impression of Nynorsk as a legitimate "hate object" may rather be confirmed and even strengthened.

Repeatedly, even politicians, especially from the conservative parties, argue against keeping Nynorsk as a second/ alternative written language in the educational system. It may also be mentioned that many Norwegian newspapers do not allow their journalists to use Nynorsk - even though it has had the status of an official and equal Norwegian language since 1885. This is yet another experience for the students that would strengthen their belief that Nynorsk is not an "important" part of the Norwegian society and it might even disappear in a relatively short time. No wonder motivation to learn the alternative language may be very low. Accordingly, most students have lower grades or even fail in Nynorsk, which may have an impact on their future professional life. This is yet another experience that would turn the students against it and form the students' attitude to the alternative language. Informed by this background, it is easy to understand that most students do not find the motivation to invest (Norton, 2013) very much effort in learning Nynorsk.

Let us compare the situation of Nynorsk as an alternative written language to English as a foreign language in the Norwegian educational system. What can we learn from foreign and second language acquisition that might help us understand the challenges connected to Nynorsk as a "second" Norwegian language? As I have argued in a previous paper on the same topic (Haugan 2017), Nynorsk as an alternative written language in the Norwegian society and educational system can be said to have more in common with a second language than with a so-called "mother tongue" or first language. One crucial term in this perspective is identity (Norton 2013; Dörnyei 2009). As Norton (2013) and Dörnyei (2009) and many others have focused on in more recent 
studies on second language acquisition, being able to identify with the target language yields much better learning results. Norton (2013: 45) states:

I use the term identity to reference how a person understands his or her relationship to the world, how that relationship is constructed across time and space, and how the person understands possibilities for the future.

Furthermore, with reference to Heller (1987), Norton (2013: 45) states:

it is through language that a person negotiates a sense of self within and across different sites at different points in time, and it is through language that a person gains access to - or is denied access to - powerful social networks that give learners the opportunity to speak. Thus language is not conceived as a neutral medium of communication, but is understood with reference to its social meaning.

As I have argued above, most Norwegian students identify with Bokmål as their "Norwegian" language, which is strengthened through experience in Norwegian society and its educational system. Students experience that they have the opportunity to write (speak) in all school subjects and the only time they experience being "denied access to powerful social networks" is if they achieve poor results in the small part of Norwegian in school that is related to the mastering of written Nynorsk. For most students this does not have a serious impact on their future prospects. Hence, language beliefs, language experience and language activity are usually neatly correlated for most students.

The approach by Norton (2013) offers several fruitful perspectives, for instance:

(ii) SLA theorists need to address how relations of power in the social world affect learners' access to the target language community; learners who may be marginalized in one site may be 
highly valued in another. Identity theorists are therefore concerned about the ways in which opportunities to practice speaking, reading and writing, acknowledged as central to the SLA process (cf. Spolsky, 1989), are socially structured in both formal and informal sites of language learning. This has important implications for the conditions under which learners speak, read or write the target language, and hence opportunities for language learning. (Norton 2013: 2)

When comparing English as a foreign or possibly second language in the Norwegian educational system and society, what are the "relations of power in the social world" and "access to the target language community"? Since the Second World War, British and American culture has had a great impact on Norwegian culture. English is taught as a separate school subject from primary school. Television and radio programming is dominated by English movies and music and English as a language generally has a very high status in Norwegian society. Many Norwegian companies choose English names instead of Norwegian names and in certain branches, English is considered a "better" language in commercial use. It is almost more common to see signs with "sale" on them than with the Norwegian word "salg". Very few companies in Norway, including those from the part of Norway where Nynorsk is used and taught as the main written variety, would choose to advertise their products in Nynorsk.

As I have discussed before, Nynorsk may be graded with a separate grade at the end of lower and upper secondary school, but Nynorsk is not a separate school subject like English, and Nynorsk is not very actively taught before the $8^{\text {th }}$ grade, whereas English has a highly visible place and status from primary school on. Although there is a debate in academia on whether English is taking over as an academic language in research and higher education, there is very little debate about the use and status of English in Norwegian society, apart from sporadic comments in the readers' columns where some people demand more Norwegian music on the radio. Compared to this, there are regular and highly polemic 
debates in all types of media on the status and the use of Nynorsk, and there are political parties that want to remove the status of Nynorsk as a mandatory school subject.

Norton (2013: 2) also states:

(iii) Identity, practices and resources are mutually constitutive. This suggests that identity is influenced by practices common to institutions such as homes, schools and workplaces, as well as available resources, whether they are symbolic or material. Examination of the practices and resources of particular settings, and of learners' differential access to those practices and resources, offers a means to theorize how identities are produced and negotiated. At the same time, structural conditions and social contexts do not entirely determine language learning or use. Through human agency, language learners who struggle to speak from one identity position may be able to reframe their relationship with others and claim alternative, more powerful identities from which to speak, read or write, thereby enhancing language acquisition.

This paragraph focusing on practices can be related to the ERL terms Language Experience and Language Activity. Students learn to read, write and express themselves in English relatively early in school, and with the introduction of the internet and social media in the past twenty years most students actively participate in international conversations where English is used as a lingua franca. The use of English in communication is hardly ever met with a negative attitude, whereas using Nynorsk in internet forums might easily lead to a debate about Nynorsk instead of the topic under discussion. Even students that have learned Nynorsk as their first and main Norwegian variety often decide to change to Bokmål because of social pressure.

Yet another aspect Norton (2013) discusses is the term investment:

(iv) The sociological construct of investment, which I developed to complement the psychological construct of motivation in SLA, is 
a construct that signals the complex relationship between language learner identity and language learning commitment. I argue that a learner may be a highly motivated language learner, but may nevertheless have little investment in the language practices of a given classroom or community. The classroom, for example, may be racist, sexist, elitist or homophobic. Alternatively, the language practices of the classroom may not be consistent with learner expectations of good teaching, with equally dire results for language learning. In sum, a learner can be highly motivated to learn a language, but not necessarily invested in a given set of language practices. However, a learner who is invested in a given set of language practices would most likely be a motivated language learner. Investment has become an important explanatory construct in language learning and teaching (Cummins 2006).

Investment is not necessarily a part of the ERL terminology. However, the terms Language Beliefs and Language Experience are related to Language Activity. Activity is the student's actual use of language based on language beliefs and language experience. In order to change language activity (and possibly beliefs) the student would have to make an extra effort, which requires investment. Investment is tightly connect to motivation. If the student is not motivated, there will be low or no investment and, hence, low or no results.

Investing in learning English obviously has direct benefits for young students. The whole world of international (AngloAmerican) pop and fashion culture opens up, which is an important part of a student's life. Traveling to other countries with family is much more common nowadays and English can be used as a lingua franca. Mastering English gives status and it is possible to obtain personal "boosts" and confirmation in the form of likes on social media such as Facebook and Instagram from a much bigger audience. It is even possible to form alternative identities in social media where English may be a great benefit. Very few students experience the same benefits using Nynorsk as their language and identity. More often than not, students using Nynorsk would have to defend 
their choice of language, and this is hardly ever an issue when using English.

Related to the aspects above, Norton (2013: 2) also states:

(v) Recent research on imagined communities and imagined identities is theoretically generative for SLA theory. The term 'imagined community', originally coined by Benedict Anderson (1991), was explored in my 2001 chapter (Norton, 2001), and further developed in Kanno and Norton (2003), Pavlenko and Norton (2007) and Norton and Gao (2008). In these publications, we argue that in many language classrooms, the target language community may be, to some extent, a reconstruction of past communities and historically constituted relationships, but also a community of the imagination, a desired community that offers possibilities for an enhanced range of identity options in the future. These ideas, inspired also by Lave and Wenger (1991) and Wenger (1998), have proved generative in diverse research sites. I have argued that an imagined community assumes an imagined identity, and a learner's investment in the target language can be understood within this context.

The terms language identity and imagined identity/identities and imagined communities are fruitful approaches when trying to understand the challenges of Nynorsk as an alternative or second Norwegian written language. Dörnyei (2009) and other researchers also use the term The L2 Self.

The years a student spends in school correlate with the years the student uses to develop his or her identity or self. The use of language, both oral and written, is an important part of a person's identity. In Norway, most people speak local or regional dialects that may differ to various degrees from the written varieties. Altering the dialect in the direction of the written language (preferably Bokmål) may lead to negative comments in certain situations (cf. language experience and the power of the social world). Oral language identity is usually related to a concrete place or region, whereas written language identity is most often neutral when it comes to the use of Bokmål. Since this language variety is used by the majority of 
Norwegians, Bokmål is usually synonymous with Norwegian, being "the" Norwegian language. Using Bokmål normally does not lead to negative feedback of any kind or require any extra effort or investment. It is not always easy for a young student to meet the challenges connected with developing or choosing a language identity related to Nynorsk. It would require a strong belief, a strong will, a strong personality and the ability to withstand constant critical feedback on his or her language activity.

In the context of foreign or second language teaching and acquisition, the notion of language identity or language self is a little weaker. The student is not expected to change his or her personal identity. Therefore, the "price" or investment is not equally high compared to actually acquiring a completely new language identity. However, when using the terms imagined language identity or imagined language community one could also refer to the term role in the ERL network. What is the educational role of language? When asked to imagine another language identity or community, students are indirectly asked to play or act a certain role in their language education. This role-playing has a didactic purpose and often has an aspect of playing, which does not necessarily affect the student's personal identity.

Norwegian students trying to learn English in primary or secondary school would have few problems imagining English speakers and communities. Norwegian students hear and read English "everywhere", i.e. on the radio, TV, in cinemas, on the internet and in certain magazines. Many students may know the streets of London, New York or Chicago better than the streets of another Norwegian city or town, since most movies on Norwegian television actually are set in the USA or Great Britain. Even on Norwegian news channels, the White House may be seen more often these days than the Norwegian parliament building. Nynorsk, on the other hand, is hardly heard anywhere. As mentioned before, most Norwegians speak their local or regional dialect and there may be significant differences between oral speech and any of the written 
varieties. However, dialects and sociolects around Oslo, the capital of Norway, tend to be closer to Bokmål. Therefore, those oral varieties are conceived of as a kind of standard by many.

As for Nynorsk, the historical approach has usually been "speak your own dialect and write Nynorsk". No official attempt has been made to form a Nynorsk oral standard. However, dialects from the west coast of Norway tend to be closer to Nynorsk, and the largest concentration of users of Nynorsk as their main written language is also in the west of Norway. Standardized oral Nynorsk is rarely heard. Laws regulating the use of the written varieties of Norwegian only apply to state organizations. For instance, the Norwegian Broadcasting Corporation (NRK) is obliged to use each of the two language varieties in at least $25 \%$ of their productions. The same law does not apply to any of the many non-state broadcasting companies. When Nynorsk is used in state news programmes, the news anchor is usually a person from western Norway. Hence, the only role model for an imagined language identity or community is related to western Norway. While learners of English often lack cultural knowledge about Great Britain or the USA which might lead to disliking certain areas or accents of English speaking communities, certain Norwegian regions and dialects may indeed feel uncomfortable or awkward to identify with for students from other regions. Trying to identify with another oral variety of Norwegian in order to master the written variety is not necessarily the same as trying to identify with an English speaking community in general. When comparing English and Nynorsk as second or alternative languages, one may find many similarities in the approach to learning, but Nynorsk clearly has far greater challenges when it comes to student motivation and investment. 


\section{Conclusions}

In this paper, I have discussed the challenges related to learning Nynorsk as an alternative written language from the perspective of the Educational Role of Language network and language acquisition approaches by Norton (2013) and Dörnyei (2009). The perspectives of Language Beliefs, Language Experience and Language Activity that are central in the ERL approach proved to be very useful when trying to understand the challenges Norwegian students meet in their educational system and society. For politicians, curriculum developers and teachers this should lead to increased awareness about the status and visibility of Nynorsk in school and society. If students believe that Norwegian is in fact the same as Bokmål, and if they experience that Bokmål in fact is synonymous with Norwegian in most of the school system and in society, the result will be that language activity will be related to Bokmål. From the perspective of Norton (2013), if the educational system and society represent social forces with the power to favour Bokmål in more or less all domains of society, motivation for and investment in learning Nynorsk in school will necessarily be very low. Furthermore, when there are few or no possibilities to actually listen to standardized Nynorsk, students are deprived of the opportunity to use an imagined language identity or community as a tool for learning and they will most likely achieve poorer results in comparison to learning English, for example.

\section{References}

Cambridge Dictionary. Available at https://dictionary.cambri dge.org/dictionary/.

Darvin, R., B. Norton (2016). "Investment and language learning in the 21 st century". Langage et société 157/3: 19-38. 
Dörnyei, Z. (2009). "The L2 motivational self system". In: Z. Dörnyei, E. Ushioda (eds.). Motivation, Language Identity and the L2 Self. Bristol - Buffalo - Toronto: Multilingual Matters.

ERL 1 (2016) - First International Pedagogical and Linguistic Conference "Educational Role of Language: Learn to speak, speak to learn", University of Gdansk, Poland 2016, 9-10 June, 2016. Available at http://www.educationalroleoflanguage.ug.edu.pl/1stconf-programme-0. Accessed 19.01.2019.

ERL 3 (2018) - Third International Pedagogic and Linguistic ERL Conference - "Educational Role of Language - How do we understand it?" Lithuanian University of Educational Sciences, Vilnius, Lithuania, June 14-15, 2018. Available at http://educa tionalroleoflanguage.ug.edu.pl/sites/default/files /ERL-III-VilniusConference-programme-FINAL.pdf. Accessed 19.01.2019.

ERL research. Available at http://educationalroleoflanguage. ug.edu.pl/erl-research. Accessed 19.01.2019.

Garrett, P. (2010). Attitudes to Language. Key Topics in Sociolinguistics. Cambridge: Cambridge University Press.

Grepstad, O. (2015). Språkfakta 2015. Ei forteljing om språk i Noreg og verda gjennom 850 tabellar. Ørsta: Nynorsk kultursentrum.

Hargreaves, A. (2003). Teaching in the Knowledge Society: Education in the Age of Insecurity. New York: Teachers College Press.

Haugan, J. (2016). "L1, L2 and the case of Norway's written language diversity: How do Norwegian schoolchildren reflect on the social and cultural linguistic world around them?". Paper presented at ERL 1 - Educational Role of Language, Gdansk, June 2016.

Haugan, J. (2017). "Language diversity in Norway and the question of L1 and L2". Beyond Philology: An International Journal of Linguistics, Literary Studies and English Language Teaching 14/1: 181-204.

Haugan, J. (2018a). "Norwegian Nynorsk - How to write student papers in a variety of your mother tongue that you actually dislike". Paper presented at ERL 3 - "Educational Role of Language", Vilnius, June 2018.

Haugan, J. (2018b). "The importance of formal grammar skills: Reflections on Polish students learning Norwegian". Beyond Philology: An International Journal of Linguistics, Literary Studies and English Language Teaching 15/1: 107-132.

Haugen, E. (1965). "Construction and reconstruction in language planning: Ivar Aasen's grammar”. Word 21/2: 188-207. 
Heller, M. (1987). "The role of language in the formation of ethnic identity". In: J. Phinney, M. Rotheram (eds.). Children's Ethnic Socialization. Newbury Park, CA: Sage, 180-200.

Læreplan i norsk (NOR1-05) (National curriculum for Norwegian as a school subject). Available at https://www.udir.no/k106/NOR105. Accessed 19.01.2019.

Nordal Steinsvik, A. (2004). Nynorsk $i$ bokmålsland: ei gransking av undervisningspraksis og haldningar til nynorsk som sidemål $i$ ungdomsskulen i Bærum. Arbeidsrapport. Høgskulen i Volda.

Nordhagen, J. (2006). Nynorsk som sidemål $i$ skolen - en undersøkelse av allmennlærerstudenters personlige og yrkesprofesjonelle holdninger. Hovudoppgåve, Universitetet i Oslo. Master's thesis.

Norsk språkforening. Available at http://norsk.atspace.com/.

Norton, B. (2013). Identity and Language Learning: Extending the Conversation. 2nd edition. Bristol, Buffalo, Toronto: Multilingual Matters.

Peirce, B. N. (1995). "Social identity, investment, and language learning". TESOL Quarterly 29/1: 9-31.

Schaffar B., Uljens M. (2015). "Paradoxical tensions between Bildung and Ausbildung in academia". In: E. Westergaard, J. S. Wiewiura (eds.). On the Facilitation of the Academy. Rotterdam: Sense Publishers, 1-15.

Schmidt, W. H., C. C. McKnight, R. T. Houang, H. C. Wang, D. E. Wiley, L. S. Cogan, et al. (2001). Why Schools Matter: A Cross-national Comparison of Curriculum and Learning. San Francisco: JosseyBass.

Udir.no. The Norwegian Directorate for Education and Training. Available at https://www.udir.no/in-english/. Accessed 19.01.2019.

Wardhaugh, R. (2010). An Introduction to Sociolinguistics. Sixth edition. West Sussex: Wiley-Blackwell.

Jens Haugan

ORCID iD: 0000-0001-9708-2038

Inland Norway University of Applied Sciences

Campus Hamar

2318 Hamar

Norway

jens.haugan@inn.no 